DOI: $10.19195 / 2353-8546.6 .10$

\author{
MARTA ZAMBRZYCKA
}

Uniwersytet Warszawski (Polska)

\title{
Ciało i trauma w ukraińskiej sztuce współczesnej
}

Body and trauma in contemporary Ukrainian art. In the text I want to show how images of the body in Ukrainian contemporary art refer to the traumatic events of the past. The experience of trauma has repercussions both on mental and bodily level and is reflected in many areas of culture. In art, trauma is manifested through deformed or diseased body. In this article I discuss the selected projects of Arsen Sawadov and Kharkiv, photographers, and of the representatives of the so called Kharkov's School of Social Photography: Serhiy Bratkov and Boris Mychajłov.

Keywords: body, trauma, contemporary Ukrainian art, photography, violence, dependence

Тело и травма в современном украинском искусстве. Статья раскрывает инструмент трансформации травмы в образ и то, как с помощью образов тела современное украинское искусство относится к травматическим событиям прошлого. Опыт травмы имеет последствия, как на психическом, так и на телесном уровне и находит свое отражение во многих областях культуры. Искусство относится к травматическим событиям, представляя деформированное или больное тело. В этой статье автор рассматривает избранные проекты Арсена Савадова и харьковских фотографов, представителей т.н. «харьковской школы» социальной фотографии: Сергея Браткова и Бориса Михайлова.

Ключевые слова: тело, травма, украинское современное искусство, фотография, насилие, зависимость

* Adres do korespondencji: Katedra Ukrainistyki, ul. Szturmowa 4, 02-678 Warszawa, pok. 417. E-mail: m.e.zambrzycka@uw.edu.pl. 


\section{Wstęp}

Tematem tekstu jest analiza obrazów ciała, za pomocą których ukraińska sztuka współczesna odwołuje się do traumatycznych wydarzeń z przeszłości. Doświadczenie traumy ma reperkusje zarówno w sferze psychicznej, jak i na poziomie cielesnym oraz znajduje odzwierciedlenie w wielu dziedzinach kultury. W sztuce przejawiać się może przez prezentowanie cielesności zdeformowanej czy chorej, a także $w$ formie obrazów ciała poddanego opresji. W artykule omawiam wybrane projekty Arsena Sawadowa i charkowskich fotografów: Serhija Bratkowa i Borysa Mychajłowa.

Długotrwała sytuacja opresji pozostawia w pamięci zbiorowej niezatarty ślad. Zarówno w odniesieniu do jednostki, jak i do narodu trafne jest stwierdzenie, że „traumatyczne zdarzenie uporczywie powraca i jest ponownie przeżywane”. Hanna Gosk stwierdza, iż:

dziedzictwo zależności kumuluje się w długim trwaniu, ewoluuje, wchodząc w związki z nową teraźniejszością, i utrwala się w różnych konfiguracjach. Czyni to na rozmaite sposoby, odciskając swój ślad na zachowaniach społecznych, stosunku do władzy, rozumieniu narodu i społeczeństwa [...] poczuciu tożsamości jednostkowej i zbiorowej $[\ldots]^{2}$.

Dziedzictwo to utrwala się również w ciele. Doświadczenie traumatyczne ma wpływ więc na wszystkie sfery życia — zarówno psychicznego, jak i fizycznego, dezintegruje tożsamość, kwestionuje nienaruszalność podmiotu i przekłada się na ponadjednostkowe relacje społeczne i polityczne.

Ukraina jest państwem, które wpisuje się w przestrzeń straumatyzowanej pamięci. Sytuacja długotrwałej zależności politycznej i kulturowej doprowadziła do wielu patologii, które dziś charakteryzują ukraińskie życie polityczne, społeczne i kulturowe. Syndrom potraumatyczny można analizować, odwołując się do wielu doświadczeń ukraińskiej historii. W tekście proponuję podział na trzy kategorie doświadczenia, które przedstawię na podstawie poszczególnych projektów artystycznych:

1. Dziedzictwo totalitaryzmu, które pociąga za sobą głęboko zakorzeniony lęk, pamięć przemocy i amnezję w wielu dziedzinach życia (historia, kultura). Związane jest $\mathrm{z}$ nim poczucie intelektualnego i mentalnego chaosu, strach lub bierność wobec wydarzeń politycznych i elit rządzących. Ten syndrom odzwierciedlają dwa projekty Arsena Sawadowa: „Zbiorowa czerwien'” i „Księga umarłych”. Podrozdział ich dotyczący nazywam „traumą przemocy”. Doświadczenie przemocy zdaje się prowadzić - zarówno na poziomie jednostkowym, jak i na poziomie doświadczenia zbiorowego - do syndromu wyparcia, rodzaju amnezji, a także zamętu tożsamościowego. O amnezji, a właściwie „atrofii pamięci”, będącej dziedzictwem doświadczonej traumy, pisze między innymi Jarosław Hrycak:

1 B. Dudek, Zaburzenie po stresie traumatycznym, Gdańsk 2003, s. 17.

${ }^{2}$ H. Gosk, Postzależnościowe cechy czasu postzależności, [w:] Historie, społeczeństwa, przestrzenie dialogu. Studia postzależnościowe w perspektywie porównawczej, red. H. Gosk, D. Kołodziejczyk, Kraków 2014, s. 301-313. 
Powiedzieć, że [...] ukraińska pamięć historyczna uległa deformacji, to za mało. Deformować można coś, co ma formę. Tu mieliśmy do czynienia raczej z atrofizacją pamięci. [...] Warto przywołać przykład sztucznie wywołanego głodu z lat 1932-33 [...] pamięć o tych tragicznych wydarzeniach zajmuje marginalne miejsce zarówno w oficjalnej polityce, jak i w świadomości ukraińskiego społeczeństwa ${ }^{3}$.

O wyraźnie widocznym „zamęcie ideowym” wspomina zaś Agnieszka Matusiak 4 .

2. Rozpad państwa radzieckiego i chaos, jaki powstał w dziedzinie życia politycznego, społecznego i kulturalnego na początku lat dziewięćdziesiątych. To doświadczenie łączy się z poczuciem bezradności wobec rozpadających się struktur społecznych i politycznych, ogromnym kryzysem tożsamościowym i ekonomicznym, poczuciem zagrożenia i wykorzenienia. W dziedzinie kultury i sztuki doświadczenie rozpadu związku radzieckiego jest związane z szybkim i powierzchownym adaptowaniem zachodnich wzorów przy jednoczesnym doświadczeniu pustki i chaosu poznawczego. Ten syndrom przedstawię na przykładzie projektów Borysa Mychajłowa „Zmierzch” i „Przy ziemi”. Ten podrozdział nazwałam „traumą rozpadu”. Lata dziewięćdziesiąte to na Ukrainie czas, w którym poczucie gwałtownej zmiany, zakończenia pewnej epoki utożsamiane było z rozpadem zastanych struktur społecznych i politycznych, a jednocześnie wiązało się z potrzebą poszukiwania nowej definicji tożsamościowej. Wspomina o tym A. Matusiak: „W krajach byłego bloku socjalistycznego trauma, związana z jego rozpadem, należy dziś do podstawowych problemów społeczno-kulturowych"5. Warto też zauważyć, iż pamięć powojennego etapu komunizmu stanowił w pierwszych latach niepodległości podstawę nostalgii za dawnym ustrojem, który w burzliwych latach dziewięćdziesiątych kojarzony był przez dużą część społeczeństwa ze stabilnością socjalną i poczuciem uczestnictwa w budowaniu politycznej potęgi.

3. Dziedzictwo zależności politycznej i kulturowej. Łączy się to z syndromem postkolonialnym, kreowaniem wzorów opresyjnej autoidentyfikacji, poczuciem własnej niższości, wstydem, stawianiem się w roli ofiary, biernym poddaniem się stygmatyzacji. Dyskurs postzależnościowy łączy się tu z refleksją nad społeczną sytuacją kobiety oraz obrazami/wyobrażeniami kobiecości utrwalonymi w ukraińskiej kulturze. Ilustracją tego rodzaju doświadczenia jest praca Serhija Braktowa „Chortyca”. Podrozdział nazwałam „traumą zależności”. Definiowanie tożsamościowej i kulturowej kondycji Ukrainy w kategoriach postzależnościowych (postkolonializm, posttotalitaryzm) staje się coraz bardziej popularne w badaniach humanistycznych. Ukraina jest bez wątpienia obszarem naznaczonym kilkuwiekowym dziedzictwem politycznej i kulturowej opresji, przy czym refleksja postzależnościowa ogranicza się najczęściej do okresu ostatnich dziesięcioleci.

3 J. Hrycak, Nowa Ukraina. Nowe interpretacje, Wrocław 2009, s. 117.

4 A. Matusiak, Między pamięcia a zapomnieniem. Trauma postkomunistyczna, Wrocław 2013, s. 10 .

5 Ibidem. 
Wszystkie trzy typy doświadczenia łączy zagadnienie ukraińskiej tożsamości, rekonstruowanej w warunkach politycznej niezależności. Długotrwałe doświadczenie traumatyczne - jak piszą John Briere i Catherine Scott w książce Podstawy terapii traumy - prowadzi do poważnych zaburzeń tożsamości ${ }^{6}$. Tamara Hundorowa stwierdza zaś, że kondycja posttotalitarna jest z natury swojej posttraumatyczna, co widać szczególnie wyraźnie w ukraińskich realiach, w których: „nie doszło do pełnego zerwania $z$ totalitarną radziecką przeszłością. Jej duch odbija się w ekscesach we współczesnej polityce, psychologii, kulturze masowej”7. Zagadnienie ukraińskiej tożsamości można więc rozpatrywać w ramach dyskursu postzależnościowego (postkolonialnego) powiązanego ściśle z refleksją nad dziedzictwem totalitarnym.

\section{Arsen Sawadow — ciało i trauma przemocy}

Jako pierwsze przedstawię dwa projekty Arsena Sawadowa (ur. 1962), jednego z najważniejszych współczesnych artystów ukraińskich ${ }^{8}$. W latach dziewięćdziesiątych i na początku XXI wieku Sawadow stworzył szereg cykli fotograficznych, pt. „Księga umarłych” („Книга мертвих”), „Zbiorowa czerwień” („Колективне червоне”) i „Donbas-Szokolad” („Донбас-Шоколад”). Twórczość Sawadowa pełni rolę swoistej terapii szokowej - wykraczając poza kategorie czysto estetyczne, artysta kieruje ostrze krytyki w ukraińską rzeczywistość, którą przepuszcza przez gruby filtr neobarokowej estetyki i postmodernistycznej gry cytatami, kontrastami, paradoksami. Jego prace to również refleksja nad traumatyczną przeszłością ojczyzny oraz bliznami, jakie pozostawiła ona w ludzkich ciałach i umysłach.

Taką właśnie - obleczoną w kunsztowny neobarokowy kostium — refleksją jest cykl fotografii „Zbiorowa czerwien”” — „zbiór zdjęć, których akcja toczy się bądź to w krwawych halach zakładów mięsnych [...], bądź to w szkarłatnym gąszczu demonstracji komunistów"9. Zrealizowany w latach 1998-1999 projekt składa się z dwóch części („Zbiorowa czerwień 1” i „Zbiorowa czerwień 2”). Zacznę od drugiej części, czyli cyklu wielkoformatowych zdjęć, których scenerią były wspomniane demonstracje komunistów. Sawadow przetwarza pochód weteranów w swego rodzaju psychodeliczny, zatopiony w gorącej czerwieni karnawał. Intensywna czerwień oraz nagromadzenie niepowiązanych z sobą przedmiotów wzbudza w odbiorcy uczucie niepokoju. Artysta przedstawia rzeczywistość nieuporządkowaną, złożoną z wielu zaprzeczają-

6 J. Briere, C. Scott, Podstawy terapii traumy. Diagnoza i metody terapeutyczne, thum. P. Nowak, Warszawa 2010, s. 171.

7 T. Hundorowa, Ciało, choroba i kicz: melancholijne sublimacje we współczesnej ukraińskiej prozie młodzieżowej, [w:] Wielkie tematy kultury w literaturach słowiańskich. Ciało, „Slavica Wratislaviensia" 153, red. A. Matusiak, Wrocław 2011, s. 55-71.

8 О. Соловйов, Турбулентні шлюзи, Київ 2006, s. 14.

9 O. Sołowiow, 15 postaci ukraińskiej sceny artystycznej czasu niepodległości, http://csw.art.pl/ upload/file/1303_press_ukrainiannews_soloviov_text.pdf (dostęp: 3.05.2016). 
cych sobie elementów, wśród których dominują symbole komunistycznej przeszłości przełamywane elementami karnawałowego szaleństwa, prowokacyjnego transwestytyzmu i nagości. Wyraźne jest tu przeciwstawienie przeszłości i teraźniejszości, pokolenia starych i młodych. Nie jest ono jednak oparte na binarnej opozycji minione-obecne, aktualne-nieaktualne, złe-dobre etc. Artysta zdaje się sugerować, iż totalitarna przeszłość, która ukształtowała percepcję rzeczywistości starszego pokolenia, blokuje zdolność do zmiany, do otwarcia się na przyszłość. Ta przeszłość wprowadza chaos, przetwarza teraźniejszość w przypadkową mieszaninę idei, poglądów, dążeń, przekonań.

Jak zauważa Tamara Hundorowa, doświadczenie totalitaryzmu ,jest głęboko traumatyczne przede wszystkim dlatego, że realnie dotyka starszego pokolenia zmuszonego do dokonywania trudnych przewartościowań" ${ }^{10}$. Takie przewartościowania często nie są możliwe, a nowa rzeczywistość jest postrzegana przez pryzmat radzieckiej przeszłości. Cytowana autorka zauważa, że posttotalitarna trauma kształtuje społeczną nieświadomość, powodując niepewność, nieprzystosowanie i bezdomność również młodszego pokolenia" ${ }^{11}$. Nieświadomość, częściowa amnezja, wypieranie lub uporczywe powracanie do zdarzeń traumatycznych, a także poczucie wyobcowania i nieprzynależności to syndromy często obserwowane u straumatyzowanych jednostek. W serii fotografii z cyklu „Zbiorowa czerwień” ta diagnoza wydaje się znajdować odzwierciedlenie. Starsze pokolenie - jakby nieświadome zmian zachodzących we współczesności - maszeruje, niosąc na transparentach upiory dawnych czasów. Młodzi stanowią w fotografiach Sawadowa element dezintegrujący - swoimi ekscentrycznymi pozami i ekstrawaganckimi strojami zaburzają porządek reprezentowany przez starszych. Częściowo obnażone ciała młodych mężczyzn zostały przystrojone zwiewnymi kobiecymi strojami, wytatuowani łysi chłopcy w wysokich wojskowych butach paradują wystrojeni w sukienki baletnic. Jak stwierdza Olga Petrowa - „w obrazie tragicznego karnawału artysta odzwierciedla mentalny i polityczny chaos postkomunistycznego państwa i demaskuje obecność totalitarnego dziedzictwa" ${ }^{\prime 2}$.

Pozostawiająca trwały ślad w społecznej mentalności, traumatyczna przeszłość to również motyw przewodni pierwszej części cyklu „Zbiorowa czerwień”. Jego scenerią są pomieszczenia rzeźni i ubojni. Bohaterowie to mężczyźni i byki, a także swoiste hybrydy będące bezpośrednim nawiązaniem do mitu Minotaura (mężczyzna z nałożoną na szyję, odciętą głową byka). Okrwawione ciała zwierząt zwisają bezwładnie, podwieszone na hakach, cała przestrzeń fotografowanych pomieszczeń unurzana jest we krwi, którą zabrudzeni są również młodzi mężczyźni przebrani w stroje torreadorów. Artysta prowadzi bardzo subtelną grę symbolami - posługując się estetyką korridy, sugeruje walkę dwóch silnych przeciwników - człowieka i groźnego zwierzęcia, umiejscawiając jednak bohaterów w pomieszczeniach rzeźni zdaje się wyraźnie suge-

10 T. Hundorowa, op. cit., s. 55-71.

11 Ibidem.

12 О. Петрова, Шокуюче як мистецтво - від бунту до ринку, „Сучасне мистецтво” 2013, nr 9, s. 93-97. 
rować, że walka jest tylko pozorna, siły nie są równe, a przeciwnik — zwierzę — jest $\mathrm{w}$ istocie skazaną na zagładę ofiarą, której los od początku był przesądzony.

Obie części cyklu „Zbiorowa czerwień” zostały połączone zdecydowaną dominacją intensywnej czerwieni, będącej zarówno znakiem komunistycznej przeszłości, jak i barwą krwi. Istotne jest, że fotografie układają się w zwartą całość, rodzaj opowieści. Jak zauważają autorzy książki Podstawy terapii traumy, właśnie tworzenie narracji - początkowo chaotycznej, z czasem coraz bardziej spójnej - stanowi jedną z podstawowych praktyk w leczeniu syndromu posttraumatycznego ${ }^{13}$.

Do doświadczeń traumatycznych nawiązuje artysta w projekcie „Księga umarłych" (2001). Na utrzymanych w ciepłej tonacji kolorystycznej fotografiach odbiorca widzi zabałaganione wnętrza przypominające skład starych przedmiotów. Pośród nich znajdują się nagie ludzkie ciała. Są jakby uśpione. W pierwszej chwili trudno zrozumieć, dlaczego te fotografie wzbudzają niepokój, dopiero przyjrzawszy się uważniej, widzimy, że ciała są nie uśpione, lecz martwe. „Księga umarłych” - jak sama nazwa wskazuje - mówi o śmierci, ale nie o śmierci ubranej w kulturowy kostium obrzędu i rytuału. Artysta przedstawia ją jako akt czysto fizjologiczny.

Jak piszą autorzy książki Podstawy terapii traumy, „trauma to zdarzenie, które wiąże się ze śmiercią, poważnymi obrażeniami [...] zagrożeniem integralności fizycznej [...] wywołuje poczucie zagrożenia, strachu, bezradności" ${ }^{14}$. Doświadczenie śmierci, lęk przed psycho-fizyczną dezintegracją to zdecydowanie jedna z najsilniejszych traum. A przecież śmierć - w walce, $\mathrm{w}$ wyniku prześladowań, represji, tortur, morderstw, porwań, a współcześnie podczas politycznych i finansowych rozgrywek, opresji politycznej i trwającej od dwóch lat wojny na wschodzie Ukrainy — można określić lejtmotivem ukraińskiej historii. Co więcej, jest to śmierć, która do dziś nie doczekała się godnego upamiętnienia. Manipulacja historią, wykorzystywanie traumatycznych przeżyć przypomina „wyciąganie trupów z grobów”. Te „trupy” to: ofiary terroru i Wielkiego Głodu, ofiary II wojny światowej, postaci historyczne, o których pamięć wykorzystywana jest jako narzędzie kreowania konkurencyjnych wersji historii. Arsen Sawadow potraktował ludzkie zwłoki bez szacunku, sugerując tym samym całkowity brak poszanowania dla tragicznej historii Ukrainy, dehumanizację życia politycznego, lecz również apatię i swoistą dysfunkcję świadomości społecznej. Bierność, z jaką większość społeczeństwa przyjmuje swoją kondycję, można porównać do objawów syndromu posttraumatycznego. Cytowani wyżej autorzy piszą: „wśród [...] egzystencjalnych następstw [traumy - M.Z.] można wyróżnić: poczucie głębokiej pustki, utratę łączności z własną duchowością lub zachwianie zdolności do pokładania nadziei i zaufania w sobie lub w innych"15. Czy nie taki właśnie apatyczny, niespójny wewnętrznie - stan świadomości dominował w ukraińskiej przestrzeni politycznej i kulturowej pierwszych lat niepodległości?

\footnotetext{
13 J. Briere, C. Scott, op. cit., s. 134.

14 Ibidem, s. 17.

15 Ibidem, s. 32.
} 
Martwe ciała z „Księgi umarłych” nawiązują też do traumatycznego doświadczenia w sferze wartości. Bohdan Dudek w książce Zaburzenie po stresie traumatycznym stwierdza, że mechanizm powstania traumy polega na dezorganizacji sfery poznawczej: „informacje płynące ze zdarzenia traumatycznego nie pasują do informacji, które są treścią podstawowych struktur poznawczych utrwalonych przez jednostkę w ciągu jej dotychczasowego życia" ${ }^{16}$. Zdarzenie traumatyczne stanowi więc całkowite zaprzeczenie przekonań, które konstytuowały obraz rzeczywistości. Doświadczenie totalitaryzmu jest tego rodzaju zaprzeczeniem. Co więcej, tak jak jednostka powraca uporczywie do wydarzenia traumatycznego, zamykając sobie drogę do kolejnych doświadczeń, tak i nieaktualne już przecież wzory, przekonania i wartości epoki komunizmu wiodą swój żywot w sferze ukraińskiej polityki i życia społecznego.

\section{Borys Mychajłow — ciało i trauma rozpadu}

Sytuacja długotrwałej zależności i opresji odcisnęła piętno na społeczeństwach obszaru poradzieckiego. Wykształciła rodzaj posttraumatycznej świadomości, prowadzącej do deformacji i patologii $\mathrm{w}$ wielu dziedzinach życia. To piętno jest widoczne również w obszarze współczesnej sztuki — zarówno w jej płaszczyźnie estetycznej, ideologicznej, jak i instytucjonalnej. Hałyna Skljarenko w artykule Сучасне мистецтво в умовах постколоніальної культури. Українська версія ${ }^{17}$ analizuје poziomy uwikłania ukraińskiej sztuki w kontekst postradzieckiego dziedzictwa i podkreśla, iż rozliczenie z przeszłością łączy się ściśle z poszukiwaniami definicji nowej tożsamości. W książce Современное искусство Украины badaczka zauważa, iż dla artystów nowej fali oraz przedstawicieli innych nowatorskich kierunków, które doszły do głosu na przełomie lat osiemdziesiątych i dziewięćdziesiątych, podstawowym adwersarzem i negatywnym punktem odniesienia pozostawała twórczość socrealistyczna i cały kompleks ideologiczny z nią związany ${ }^{18}$.

Pseudorealistycznej, propagandowej sztuce poprzedniej epoki pokolenie nowej fali przeciwstawiało barwny, eklektyczny wielogłos, oddający puls współczesności ${ }^{19}$. Lecz pod owym karnawałem skrywało się właściwe sytuacji posttotalitarnej odczucie bezładu, chaosu i głębokiego niepokoju. Czerpiąc z niedostępnego wcześniej doświadczenia sztuki zachodniej, ukraińscy twórcy wprowadzali na rodzimy grunt performance, happening, nową fotografię, malarstwo abstrakcyjne oraz tendencje postmodernistyczne, poszukując $\mathrm{w}$ tych doświadczeniach podstaw autoidentyfikacji, dążąc do ukonstytuowania nowej rzeczywistości. Warto podkreślić, że ów pierwszy etap rozwoju nowatorskich tendencji charakteryzował się znacznym bezładem, po-

16 B. Dudek, op. cit., s. 37.

17 Г. Скляренко, Сучасне мистецтво в умовах постколоніальної культури. Украйнська версія, „Сучасне мистецтво. Науковий збірник” 2004, nr 1, s. 83-97.

18 Г. Скляренко, Современное искусство Украины, Киев 2015, s. 11.

19 Ibidem. 
mieszaniem ideologicznym i estetycznym, stanowił swego rodzaju „zachłyśnięcie się" wolnością i nowymi możliwościami. Hlib Wyszesławski w tekście Постмодерністські тенденції у сучасному візуальному мистецтві України кіния 80mих початку 90 mux pp stwierdza, iż błyskawiczne tempo przyswajania tendencji, które na Zachodzie rozwijały się przez dziesięciolecia, spowodowało wymieszanie i współwystępowanie stylów, kierunków i poglądów artystycznych, często stojących $\mathrm{z}$ sobą w sprzeczności ${ }^{20}$. Poszukiwania artystyczne nie konstytuowały więc zwartej wizji nowej rzeczywistości, a raczej odzwierciedlały sytuację bezładu i poznawczej bezradności. Uświadamiały również ogrom białych plam, niewiedzy spowodowanej dziesięcioleciami izolacji. Spod tygla artystycznego eklektyzmu wyzierała postkomunistyczna ruina, świat zdewastowany, rzeczywistość, z którą trzeba się uporać, którą należy dostrzec $w$ całej jej brzydocie.

Autorki książki Trauma. Proces i diagnoza piszą, że przeżyta trauma „wywraca świat do góry nogami”, a pamięć o niej już na zawsze pozostawia ślad w psychice, aktualizuje się od czasu do czasu w formie poczucia kruchości i złudności otaczającego świata: „silna trauma [...] powoduje, że świat staje do góry nogami. [...] otwiera drogę do lęku, przygnębienia, myślenia, że robienie czegokolwiek pozbawione jest sensu, bo w każdej chwili wszystko może lec w gruzy"21. Wielu artystów, w tym światowej sławy fotograf Borys Mychajłow, rejestruje psychologiczną apatię będącą poradzieckim dziedzictwem. Ludmiła Bereznickaja określa działalność Borysa Mychajłowa jako długą opowieść o pokoleniach żyjących z posttotalitarnym syndromem ${ }^{22}$. Sam fotograf mówi, że jego prace są tekstami składającymi się na opowieść o poradzieckiej rzeczywistości, o jej przeszłości i pojawiających się wciąż nowych problemach ${ }^{23}$.

Fotografie Borysa Michajłowa z cykli „Zmierzchy” („Сумерки”) oraz „Przy ziemi” („У земли”) zrealizowane na początku lat dziewięćdziesiątych składają się na obraz „świata po apokalipsie”, w którym dominują brud, choroba, degeneracja. Ludzkie ciało - chore, stare, zniszczone - jest tu motywem przewodnim. W fotografiach dominuje poczucie beznadziei i swego rodzaju bezwstydu w epatowaniu ludzkim poniżeniem. Widzimy tu osoby dorosłe i nastolatków, dzieci oraz ludzi w zaawansowanym wieku, zdrowych i inwalidów. Łączy ich apatyczna postawa, tępe zapatrzenie $\mathrm{w}$ dal. Wszyscy są odarci z prywatności, wyrwani z zacisza domu, ich życie toczy się na ulicy w zimnej i zaśmieconej przestrzeni. Fotografie z cykli „Zmierzch” i „Przy ziemi” układają się w opowieść o ciągu szarych, męczących dni, które mijają, nie zmierzając do żadnego celu. Ukazane przez Mychajłowa ulice, podwórka i bazary stają się rzeczywistością bez wyjścia. Taka apatia, brak dążenia do wartości wyższych, niedbałość i brak szacunku do samego siebie to syndromy charakterystyczne

20 Г. Вишеславський, Постмодерністські тенденції у сучасному візуальному мистеитві України кіния 80-тих початку 90 тих рр, „Сучасне мистецтво” 2007, nr 4, s. 93-146.

21 E. Zdankiewicz-Ścigała, M. Przybylska, Trauma. Proces i diagnoza, Warszawa 2002, s. 8.

22 Л. Березницкая, Борис Михайлов: «Я думаю, что соучастие - это характеристика моего метода в искусстве», http://artukraine.com.ua (dostęp: 5.04.2013).

${ }^{23}$ Ibidem. 
dla psychologii traumy, wraz z poczuciem bezradności prowadzą do biernej zgody na istniejącą rzeczywistość i odbierają zdolność do walki o poprawę własnego losu.

Obniżone kadrowanie, polegające na fotografowaniu $\mathrm{z}$ wysokości biodra, ukazuje świat w zawężonej perspektywie, odbiorca odnosi wrażenie, że znalazł się w ciasnej klatce, niepozwalającej wznieść się ponad poziom chodnika, ulicy, ziemi. Właśnie w takiej perspektywie, na takim poziomie toczy się życie bohaterów obu serii Mychajłowa. Klaustrofobicznego wrażenia dopełnia ponura monotonna kolorystyka, w serii „Zmierzch” ciemnogranatowa, w „Przy ziemi” - brązowa. Warto zauważyć, iż poczucie ograniczenia i zawężenia perspektywy życiowej stanowi jeden z psychologicznych skutków traumy ${ }^{24}$. W wywiadzie z Ludmiłą Berezicką artysta podkreśla, że poradzieckie dziedzictwo do dziś tkwi w ukraińskim społeczeństwie, a jego zrozumienie możliwe jest jedynie przez swego rodzaju przepracowanie zdarzeń traumatycznych, opowiadanie o nich, poszukiwanie w nich sensu i dotarcie poprzez nie do źródeł współczesnych problemów. To dziedzictwo można nazwać swego rodzaju chorobą, i właśnie do tej fizjologicznej kategorii odwołuje się artysta w swojej bodajże najbardziej znanej serii zatytułowanej „Historia choroby”. Jest to cykl zdjęć charkowskich bezdomnych, wykonanych w latach 1997-1998. Fotografując bezdomnych, Borys Mychajłow zdaje się sugerować rozpad i pustkę przedstawianej rzeczywistości. Warto jednak mieć na uwadze, że pamięć poradzieckiej przestrzeni nie jest tak jednoznaczna i zawiera w sobie zarówno doświadczenie traumy, jak i nostalgię ${ }^{25}$. Uproszczeniem byłoby również mówienie o całkowitym rozpadzie i pustce poradzieckiej rzeczywistości, która jest „,nie tyle próżnią, ile wielką nieprzejrzystością, rzeczywistością wypełnioną z jednej strony trwaniem przy starych modelach, $\mathrm{z}$ drugiej zaś poszukiwaniem nowych dróg i rozwiązań" ${ }^{26}$. Próbą poszukiwania nowej drogi jest chociażby zyskująca coraz większą przychylność refleksja postkolonialna i postzależnościowa, która - przeniesiona w realia przestrzeni postsowieckiej - pozwala stosować współczesne humanistyczne instrumentarium badawcze i prowadzi do ożywczych poznawczo interpretacji.

\section{Serhij Bratkow — ciało i trauma zależności}

Ryszard Kupidura zauważa, iż ukraińskie środowiska intelektualne w większości definiują sytuację swojego kraju jako postkolonialną ${ }^{27}$. Ukrainoznawcze badania postkolonialne koncentrują się przede wszystkim na dziedzictwie ostatnich dziesięcioleci, jednak pamięć zależności sięga o wiele dawniejszych kart ukraińskiej historii.

${ }^{24}$ M. Dragan, Doświadczenia traumatyczne a uzależnienie od alkoholu, Warszawa 2008, s. 20.

25 C. Şandaru, O marginalizacji pamięci, [w:] Historie, spoleczeństwa ..., s. 387-405.

26 J. Wierzejska, Hermeneutyka przestrzeni postsowieckiej, [w:] Historie, społeczeństwa..., s. $405-423$.

27 R. Kupidura, Teoria postkolonialna na Ukrainie, [w:] Dyskurs postkolonialny we wspótczesnej literaturze i kulturze Europy Środkowo-Wschodniej, red. B. Bakuła et al., Poznań 2015, s. 250-280. 
To długotrwałe doświadczenie kulturowego i politycznego zniewolenia widoczne jest dziś choćby w sferze języka ukraińskiego przez lata spychanego do „pozycji narzecza używanego w rezerwacie" 28 . Podobnie jak język, tak i cała ukraińska kultura była przez stulecia sprowadzana do rangi barwnego, choć nie zasługującego na poważniejsze potraktowanie regionalizmu i ukazywana w konwencji „cepeliowo-operetkowej”. Tragicznym skutkiem tego dziedzictwa jest dominujący w ukraińskim społeczeństwie rodzaj postzależnościowej tożsamości, która prowadzi do identyfikacji własnej kultury jako podporządkowanej i „gorszej”. Mykoła Riabczuk, analizując sytuację Ukrainy w kategoriach postkolonialnych, zauważa, że każdy kolonizowany naród „stopniowo przyswaja negatywny obraz samego siebie, który jest mu narzucany przez kolonizatora" ${ }^{29}$. Dyskurs zależności umiejscawia kulturę ukraińską w roli ofiary, podmiotu podrzędnego, deformuje mentalność, ale też wpływa na postrzeganie Ukrainy na Zachodzie, który bezkrytycznie przyjmuje imperialistyczny rosyjski sposób widzenia poradzieckiej przestrzeni ${ }^{30}$.

Problematyka postzależnościowa i związana $\mathrm{z}$ badaniem wymiarów podporządkowania jest w ukraińskiej przestrzeni humanistycznej dość często łączona z refleksją nad społeczną i kulturową sytuacją kobiety. Sytuację kobiety jako podmiotu opresjonowanego zarówno w wymiarze indywidualnym, jak i polityczno-społeczno-historycznym opisuje chociażby Oksana Zabużko w powieści Badania terenowe nad ukraińskim seksem. Zgodnie ze słowami Pauliny Olechowskiej narzędziem opresji jest u Zabużko zarówno historyczne doświadczenie zależności politycznej, jak i patriarchalna kultura. Powieść jest jednym z wielu głosów ukazujących proces budowania posttraumatycznej osobowości ${ }^{31}$. Z kolei w zbiorze esejów Kroniki Fortynbrasa pisarka zauważa, że analiza traumy kolonializmu w aspekcie genderowym jest istotnym kierunkiem badań, którego rozwój otwiera dla ukraińskiej humanistyki nowe horyzonty poznawcze ${ }^{32}$. Narzędziem opresji jest dla autorki zarówno historyczne doświadczenie zależności politycznej, jak i patriarchalna kultura ${ }^{33}$. Genderowo-postkolonialna perspektywa jest charakterystyczna dla wielu ukraińskich badaczek, w tym dla Tamary Hundorowej, Wiry Ahajewej czy Niny Zborowskiej. Podobną refleksję znajdziemy w ukraińskiej sztuce współczesnej, przede wszystkim w twórczości Oksany Czepełyk, dla której indywidualne ciało kobiety jest nośnikiem treści o szerokim, społeczno-politycznym wydźwięku. Połączenie refleksji nad postzależnościową kondycją ukraińskiego społeczeństwa $\mathrm{z}$ nawiązaniem, a następnie zanegowaniem stereotypowych, utrwalonych przez literaturę i kulturę obrazów kobiecości można znaleźć również w pracy Serhija Bratkowa Chortyca (Хоритuя).

28 B. Bakuła, Współczesne debaty narodowe w Europie Środkowo-Wschodniej, [w:] Historie, spoleczeństwa..., s. 154.

29 M. Riabczuk, Ukraina. Syndrom postkolonialny, oprac. zbiorowe, Wrocław 2004, s. 57.

30 M. Riabczuk, Eurazja jako eufemizm, [w:] Historie, społeczeństwa ..., s. 167-179.

31 M. Riabczuk, Dwie Ukrainy, thum. M. Dyhas et al., Wrocław 2004, s. 366.

32 О. Забужко, Хроніки від Фортінбраса, Київ 2009, s. 154.

33 M. Riabczuk, Dwie Ukrainy..., s. 366. 
Zaprezentowana na wystawie w kijowskim PinchukArtCentre 2010 roku fotografia ukazuje młodą kobietę leżącą nad Dnieprem. Nazwa pracy, lokalizacja bohaterki, a także jej ludowy strój i wianek na głowie wpisują Chortycę w uniwersum "emblematów ukraińskości” - czyli odwołań do kozaczyzny i tradycyjnej kultury ludowej. Bratkow wykorzystał jednak tę symbolikę, aby wzmocnić kontrast i bulwersującą wymowę swojej pracy. Wianek - symbol niewinności i ukraińskiego folkloru - został bowiem zestawiony z bezwstydną pozą leżącej kobiety, która rozkładając nogi, ukazuje obnażone intymne części ciała. Dodatkowym elementem kontrastowym są wyzywające buty na bardzo wysokich obcasach oraz ciemne okulary, skrywające oczy leżącej kobiety. Praca Serhija Bratkowa wywołała oburzenie i została oprotestowana zarówno przez prawicową młodzieżówkę, jak i przez aktywistki Femenu. Przyczyn oburzenia Chortyca można szukać przede wszystkim w tym, że uderzyła ona w symbol kobiety-Ukrainy, łączący się z najwyższymi wartościami narodowymi. Uznano ją również za uwłaczającą godności ukraińskich kobiet, utwierdzającą patriarchalny sposób ich traktowania.

Bez wątpienia Chortyca wpisuje się w ramy patriarchalnych wyobrażeń o kobiecie jako o podmiocie podporządkowanym. Metanarracją jest tu zdecydowanie męski, a właściwie szowinistyczny punkt widzenia, sprowadzający kobietę do rangi obiektu seksualnego. Jest to oczywiście zabieg celowy, za pomocą którego artysta kreuje obraz ofiary, podkreślając jej zależność i podporządkowany status. Ciało kobiety, bierne i wystawione na spojrzenia innych, staje się „,tekstem, w który wpisywane są stosunki wiedzy/władzy"34. A są to władza i wiedza przebiegające na wielu poziomach życia i realizowane zarówno w przestrzeni osobistej, społecznej, jak i politycznej. Uprzedmiotawiająca kompozycja sprowadza ciało kobiety do rangi obiektu, odbiera mu indywidualizm i godność, lecz także sugeruje zgodę na ten status. Przyjmując wyzywającą pozę, kobieta godzi się na rolę przedmiotu, potwierdzając tym samym swoją społeczną niższość. Ten mechanizm konstytuowania własnej tożsamości za pośrednictwem narzuconych z zewnątrz norm i przekonań dotyczy zarówno kobiecości w jej wymiarze cielesnym i społecznym, jak i odzwierciedla opisany przez Mykołę Riabczuka syndrom powstawania tożsamości postzależnościowej, w którą wpisany jest kompleks niższości. Chortyca jest więc pracą, która za pośrednictwem obrazu kobiecego ciała podejmuje refleksję nad postkolonialnym syndromem współczesnego ukraińskiego społeczeństwa.

Ważnym wymiarem Chortycy jest odwołanie do jednego z utrwalonych w ukraińskiej tradycji obrazów, a mianowicie wyobrażenia kobiety-ojczyzny/kobiety-Ukrainy ${ }^{35}$. Widok Dniepru, atrybuty kultury tradycyjnej, nazwa odwołująca się do lokalizacji Siczy Zaproskiej - to wszystko składa się na kompleks wyobrażeń ojczyzny — przedmiotu dumy i źródła tradycyjnych wartości. W ukraińskiej tradycji ojczyzna łączy się z pojęciami bólu, cierpienia, krzywdy i poniżenia. Ukraina jako płacząca

34 Z. Melosik, Tożsamość, ciało, władza, Poznań-Torun 1996, s. 75.

35 A. Nowacki, Kobieta $w$ literaturze ukraińskiej: wspótczesne modyfikacje, [w:] Kobieta we wspótczesnej kulturze ukraińskiej, red. K. Jakubowska-Krawczyk, Warszawa 2013, s. 45. 
matka czy upokorzona dziewczyna funkcjonuje w tradycji literackiej od czasów Tarasa Szewczenki, jednak pole semantyczne związane z ojczyzną zawiera zarówno pojęcia krzywdy, jak i czystości, współczucia, niewinności i godności. Serhij Bratkow w sposób brutalny rozbija ten kompleks pojęciowy, a sprowadzając go do poziomu pornografii, wywołuje ciąg skojarzeń związanych z uczuciami pogardy, poniżenia czy zażenowania. Ukraina nie jest tu zasługującą na szacunek cierpiętnicą, lecz podmiotem uwikłanym w sytuację opresyjną.

Nie ulega wątpliwości, że „nawyki umysłu ukształtowanego przez dziesięciolecia totalitaryzmu wciąż rzutują na dyskurs publiczny i prywatny, jak również na wytwory kultury" ${ }^{36}$. Syndrom postzależnościowy odciska swoje piętno zarówno w sferze polityki, jak i w sztuce, blokuje rozwój demokratycznych relacji społecznych, utrudnia refleksję opartą na nowoczesnej metodologii badawczej. Sofia Filonenko zauważa, że opór, z jakim dyskurs postzależnościowy spotyka się w ukraińskiej humanistyce, jest uwarunkowany nieprzepracowaniem kolonialnego spadku ${ }^{37}$. Mimo to artyści próbują zachęcić odbiorcę do refleksji nad psychofizyczną kondycją współczesnego mieszkańca posttotalitarnej przestrzeni. Twórcy tacy, jak Arsen Sawadow, Serhij Bratkow czy Borys Mychajłow łączą problematykę somatyczną z szeroko zakrojoną refleksją nad posttotalitarną kondycją współczesnej ukraińskiej kultury. W ich pracach ukraińskie ciało zostaje wpisane w kontekst tragicznej historii i patologii życia politycznego. Artystyczna refleksja nad sferą somatyczną jest równie ważna jak analizy psychologicznych, historycznych czy politycznych aspektów ukraińskiej kultury, gdyż, jak pisze cytowana już Tamara Hundorowa, „przeszłość — kolonialna, radziecka, totalitarna — pożera nie tylko współczesność, ale i ciało"38.

\section{Bibliografia}

Bakuła B., Współczesne debaty narodowe w Europie Środkowo-Wschodniej, [w:] Historie, społeczeństwa, przestrzenie dialogu. Studia postzależnościowe w perspektywie porównawczej, red. H. Gosk, D. Kołodziejczyk, Universitas, Kraków 2014, s. 141-167.

Briere J., Scott C., Podstawy terapii traumy. Diagnoza i metody terapeutyczne, Instytut Psychologii Zdrowia, Warszawa 2010.

Dragan M., Doświadczenia traumatyczne a uzależnienie od alkoholu, Wydawnictwo UW, Warszawa 2008.

Dudek B., Zaburzenie po stresie traumatycznym, GWP, Gdańsk 2003.

Gosk H., Postzależnościowe cechy czasu postzależności, [w:] Historie, społeczeństwa, przestrzenie dialogu. Studia postzależnościowe w perspektywie porównawczej, red. H. Gosk, D. Kołodziejczyk, Universitas, Kraków 2014, s. 301-313.

Hrycak J., Nowa Ukraina. Nowe interpretacje, KEW, Wrocław 2009.

36 C. Şandaru, op. cit., s. 387-405.

37 С. Філоненко, Концепція особистості жінки в украйнській жіночій прозі 90-х років ХХ століття, Ніжин 2006, s. 4.

38 T. Hundorowa, op. cit., s. 60.

Miscellanea Posttotalitariana Wratislaviensia 6/2017

(C) for this edition by CNS 
Hundorowa T., Ciało, choroba i kicz: melancholijne sublimacje we współczesnej ukraińskiej prozie młodzieżowej, [w:] Wielkie tematy kultury w literaturach słowiańskich. Ciało, „Slavica Wratislaviensia” 153, red. A. Matusiak, Wydawnictwo Uniwersytetu Wrocławskiego, Wrocław 2011, s. 55-71.

Jaxa-Rożen H., Sztuka krytyczna jako refleksja nad estetyzacja ciała, [w:] Ciało cielesne, red. K. Konarska, Wydawnictwo Uniwersytetu Wrocławskiego, Wrocław 2011, s. 115-122.

Kupidura R., Teoria postkolonialna na Ukrainie, [w:] Dyskurs postkolonialny we współczesnej literaturze $i$ kulturze Europy Środkowo-Wschodniej, red. B. Bakuła et al., Bonami, Poznań 2015, s. 250-280.

Matusiak A., Między pamięcia a zapomnieniem. Trauma postkomunistyczna, „Miscellanea Posttotalitariana Wratislaviensia" 2013, nr 1, s. 9-29.

Melosik Z., Tożsamość, ciało, władza, Impuls, Poznań-Toruń 1996.

Nowacki A., Kobieta w literaturze ukraińskiej: współczesne modyfikacje, [w:] Kobieta we współczesnej kulturze ukraińskiej, red. K. Jakubowska-Krawczyk, Katedra Ukrainistyki UW, Warszawa 2013, s. $43-52$.

Popiel A., Pragłowska E., Psychopatologia reakcji na traumatyczne wydarzenia, [w:] Konsekwencje psychiczne traumy: uwarunkowania i terapia, red. J. Strelau, B. Zawadzki, M. Kaczmarek, Scholar, Warszawa 2009, s. 34-63.

Riabczuk M., Dwie Ukrainy, tłum. M. Dyhas et al., KEW, Wrocław 2004.

Riabczuk M., Eurazja jako eufemizm, [w:] Historie, społeczeństwa, przestrzenie dialogu. Studia postzależnościowe w perspektywie porównawczej, red. H. Gosk, D. Kołodziejczyk, Universitas, Kraków 2014, s. 167-179.

Riabczuk M., Ukraina. Syndrom postkolonialny, KEW, Wrocław-Wojnowice 2015.

Şandaru C., O marginalizacji pamięci, [w:] Historie, społeczeństwa, przestrzenie dialogu. Studia postzależnościowe w perspektywie porównawczej, red. H. Gosk, D. Kołodziejczyk, Universitas, Kraków 2014, s. 387-405.

Sołowiow O., 15 postaci ukraińskiej sceny artystycznej czasu niepodległości, http://csw.art.pl/upload/ file/1303_press_ukrainiannews_soloviov_text.pdf.

Wierzejska J., Hermeneutyka przestrzeni postsowieckiej, [w:] Historie, społeczeństwa, przestrzenie dialogu. Studia postzależnościowe w perspektywie porównawczej, red. H. Gosk, D. Kołodziejczyk, Universitas, Kraków 2014, s. 405-423.

Zdankiewicz-Ścigała E., Przybylska M., Trauma. Proces i diagnoza, Wydawnictwo Instytutu Psychologii PAN, Warszawa 2002.

Березницкая Л., Борис Михайлов: «Я думаю, что соучастие - это характеристика моего метода в искусстве», http://artukraine.com.ua.

Вишеславський Г., Постмодерністські тендениіі у сучасному візуальному мистецтві України кіния 80-тих початку 90 тих рр, „Сучасне мистецтво” 2007, $\mathrm{nr}$ 4, s. 93-146.

Забужко О., Хроніки від Фортінбраса, Факт, Київ 2009.

Петрова О., Шокуюче як мистеитво - від бунту до ринку, „Сучасне мистецтво” 2013, nr IX, s. 93-97.

Філоненко С., Концепиія особистості жінки в украӥнській жіночій прозі 90-х років ХХ століття, Аспект-Поліграф, Ніжин 2006.

Чермалих Н., Пагуліч Л., Ярманова Г., Гриценко Г., Гендер, релігія і націоналізм в Україні, ВТС ПРИНТ, Київ 2012.

Przyjęto do druku/Accepted for publication: 3.02.2017

Miscellanea Posttotalitariana Wratislaviensia 6/2017

(C) for this edition by CNS 